\title{
RAPID INVASION OF THE SLUG KRYNICKILLUS MELANOCEPHALUS KALENICZENKO, 1851 IN SWEDEN AND SOME NOTES ON THE BIOLOGY AND ANTHROPOCHOROUS SPREAD OF THE SPECIES IN EUROPE (GASTROPODA: EUPULMONATA: AGRIOLIMACIDAE)
}

\author{
TED VON PROSCHWITZ ${ }^{1,2}$
}

\author{
${ }^{1}$ Gothenburg Natural History Museum, Box 7283, 40235 Gothenburg, Sweden \\ ${ }^{2}$ Gothenburg Global Biodiversity Centre, University of Gothenburg, Box 461, 40530 Gothenburg, Sweden \\ (e-mail: ted.v.proschwitz@vgregion.se)
}

\begin{abstract}
The terrestrial slug Krynickillus melanocephalus, native to the Caucasus and adjacent areas, has in the latter decades, by means of man-mediated (anthropochorous) dispersal, spread westwards over areas of the former USSR, central, and northern Europe. The first record in Sweden could be traced back to 2015, and during the autumn 201930 further occurrences, mainly in the eastern parts of the country, were confirmed. The habitats are in most cases gardens, but it has also spread into adjacent waste land and man-influenced woodlands. The species is highly invasive and colonises disturbed habitats where it forms large populations. Its feeding habits and possible pest status need to be studied. Further rapid spread, both west- and southwards in Europe, is to be expected. The external appearance and genital morphology of K. melanocephalus in Swedish populations are briefly described.
\end{abstract}

KEY WORDS: Man-mediated spread; invasive species; pest-slug; Eupulmonata; Agriolimacide; limes norrlandicus

\section{INTRODUCTION}

The Swedish slug fauna comprises 23 species, of which no less than 13 (57\%) are non-indigenous and anthropochorous (VON PROSCHWITZ 2009, 2018). Many slug species have, by the help of man, inadvertently been spread over vast areas of the world, e.g. Deroceras invadens Reise, Hutchinson, Schunack et Schlitt, 2011 (REISE et al. 2011, HUTCHINSON et al. 2014). Activities such as trade with ornamental plants, transports of soil, flowerpots and pellets, as well as dumping of soil and garden waste may function as means of dispersal (e.g. BERGEY et al. 2014). Some species are highly invasive, and some of them may also become severe pests in agriculture, cultivations and gardens (cf. ROBINSON 1999, KOZŁOWSKI 2012, RowsON et al. 2014, ZAJĄC et al. 2017). One of the worst pest slugs is Arion vulgaris (MoquinTandon, 1855), a species causing immense problems and damage all over Europe both in gardens and cultivations (RABITSCH 2006) and also spreading into natural habitats (VON PROSCHWITZ 1997) and hybridising with native species (REISE et al. 2020). RABITSCH (2006) and ZAJĄC et al. (2017) even consider A. vulgaris as one of the 100 worst invasive pest species of Europe. The passive spread of other slug species may be rapid and effective, but less dramatic as they do not appear as pests or do not draw attention, or for other reasons such as size or/and colour. An example of such a species is Boettgerilla pallens Simroth, 1912 (REISE et al. 2000), with its wormlike appearance and its partly subterranean way of life. The anthropochorous spread of slugs is an ongoing, dynamic process in which unexpected species may suddenly appear in unexpected places (e.g. VON Proschwitz et al. 2017). 


\section{NATURAL DISTRIBUTION}

The locus typicus of Krynickillus melanocephalus Kaleniczenko, 1851 is the area of Stavropol in Caucasian Russia (KALENICZENKO 1851). Its natural distribution is Caucasian and it is restricted to the
Caucasian Russia, the Caucasus republics, eastern Turkey and Northern Iran (SIMROTH 1901, LIKHAREV \& WIKTOR 1980, WIKTOR 2000, 2007, WIKTOR \& JURKOWSKA 2007, SYSOEV \& SCHILEYKO 2009).

\section{ANTHOPOCHOROUS SPREAD}

The man-mediated spread of $K$. melanocephalus first drew attention in the 1990s. Outside its native area the species was first recorded in Bad Tennstedt, Thuringia (Germany) in 1994, and in 1997 and 1998 in further localities in the urban area of Erfurt (MENG \& BÖSSNECK 1999). Further survey in the city area of Erfurt until 2020 revealed a rather modest spread (BÖSSNECK \& FELDMANN 2003). An additional German record was made in an area of riparian forest in Leipzig, Saxony in 2014 (BORLEIS 2018). During the last one and a half decade K. melanocephalus has spread over the western parts of the Russian Federation (SCHIKOV 2012) and adjacent countries (former USSR): Latvia (WIKTOR \& JURKOWSKA 2007, ŠTEFFEK et al. 2008, DREIJERS et al. 2017) [first record 1997]; Ukraine (KoROL \& KORNIUSHIN 2002, GURAL-SVERLOVA et al. 2009) [first record 2001]; Belarus (BUGA \& SINCHUK 2016, OstROVSKY 2017)

\section{ERRONEOUS DATA OF OCCURRENCE}

ŠTEFFEK et al. (2008: 80) write: "K. melanocephalus appears to be an invasive species, which is known from several localities in Hungary, Bulgaria, Turkey, Poland and Israel (WIKTOR 2004)." Here the authors must have made some kind of mistake - the cited reference is WIKTOR's Polish Fauna (2004), and in this $K$. melanocephalus is not mentioned at all. Eastern Turkey is part of the species' natural distribution, but no anthropochorous spread has been reported from that country. In Hungary the known records are from 2019 (TURÓcI et al. 2020). Neither are such occurrences cited in any malacological publications dealing with the slug fauna of

\section{FIRST RECORDS IN SWEDEN}

In the autumn of 2019, I received photos (J. Roth) and material (S. Wadelius) of an unidentified slug from a garden in Virsbo, province Västmanland, Middle Sweden (red dot in Fig. 1; 59 $52.57^{\prime} \mathrm{N}$, $\left.16^{\circ} 03.97^{\prime} \mathrm{E}\right)$. The photos immediately indicated that this might be $K$. melanocephalus, until then unknown from Sweden. This could be confirmed lat- [first record 2001]; and Lithuania (STALAŽs et al. 2018) [first record 2017]. It has also recently been reported from Estonia (Estonian colleagues in mail to J. Linnander, Swedish Environmental Protection Agency) and in addition there are unpublished records [first 2017] from the south of Finland (LIUKKO \& KÖNÖNEN 2020; further information from K. Könönen in e-mail). K. melanocephalus has also been found in Northern Hungary during 2019 (TURÓcI et al. 2020). Especially in Latvia, there seems to have been an extremely fast spread, the species now being a common slug in the country with more than 50 known sites - cf. distribution map in https://www. mammadaba.lv/en/news/3058-attention-slug-krynickillus-melanocephalus. A similar pattern can be seen also in N. Hungary, with 14 localities in 2019 (TURÓcI et al. 2020).

Poland or Israel (e.g. WIKTOR 1983, 2007, HELLER 2009) nor in other papers on the slug in more comprehensive works on the European land molluscs (e.g. Welter-SChUltes 2012). A search on the web and in scientific literature databases of the above given countries connected with records of $K$. melanocephalus was also negative. The old references of occurrences in Romania (GROSSU \& LUPU 1957) and Bulgaria (URBAŃSKI \& WIKTOR 1968) are due to confusion with the closely related, at that time undescribed, Krynickillus urbanskii (Wiktor, 1971) (WIKTOR 1971, 2000).

er based on anatomical characters of specimens sent in. An old photograph allowed us to trace back the first occurrence of this species in the garden to 2015. Due to the potential invasiveness of this species both the Swedish Species Information Centre (ArtDatabanken) and the Swedish Environmental Protection Agency (Naturvårdsverket) became in- 
volved and information of the record spread rapidly on the web and in media. During the following weeks, further information, pictures and slugs were received from the public. Some records could be identified as belonging to other species, but until the 23rd November 201931 records could be confirmed as $K$. melanocephalus. They are distributed from the south-eastern part of the province of Halland in the south-west, through the eastern Swedish provinces of Småland, Södermanland, Uppland, Närke, Västmanland, Gästrikland to, so far, the northernmost locality at Vallvik in the coastal area of the Provinve of Hälsingland $\left(61^{\circ} 19.98^{\prime} \mathrm{N}\right.$, $\left.17^{\circ} 11.01^{\prime} \mathrm{E}\right)$ (Fig. 1). Some of the reported localities lie very close to each other (adjacent gardens, etc.) so the total markings in the map are only 16 . Vouchers for all records are kept, as specimens or photos, in the Gothenburg Natural History museum. So far all records are situated south of the so called limes norrlandicus, which is an important biogeographical transition zone, running through the middle of Sweden, north of Lake Vänern in the West, eastwards with a marked prolongation northwards to approx. $62^{\circ} \mathrm{N}$ along the Baltic Sea coast. It is often referred to as the northern distribution limit of the oak (Quercus robur). Within this zone the northern limits of many deciduous trees and other vascular plants as well as of several animal species cluster, and it is also the southern limit of many organisms (FRIES 1948). Many native land mollusc species have their northern limit in the limes area, among the slugs Arion ater (Linnaeus, 1758). Also some introduced species, such as Arion rufus (Linnaeus, 1758), have not established populations north of the limes, whereas others, e.g. A. vulgaris have done so (VON PROSCHWITZ 2014).

\section{BIOLOGICAL OBSERVATIONS}

Although the vast majorities of the records are from gardens, there are also a few from, often adjacent, strongly man-influenced woodlands etc. In the Virsbo-area K. melanocephaus was also confirmed from semi-open bushland, adjacent to the gardens. The total area of occurrence at this site was estimated at approximately $25,000 \mathrm{~m}^{2}$. In Östansjö, in the province of Närke, it was found both in gardens and in adjacent man-influenced woodlands. The abundance was usually characterised as "a few", but in a few cases as "numerous" - the number of specimens in Virsbo was estimated by the County administrative board of Västmanland as 100,000 in one block of gardens (U. Bjelke, in email). It should be noticed, however, that most of the observations were made late in the year (October-November) when the slugs are fully grown and easy to find. After in-

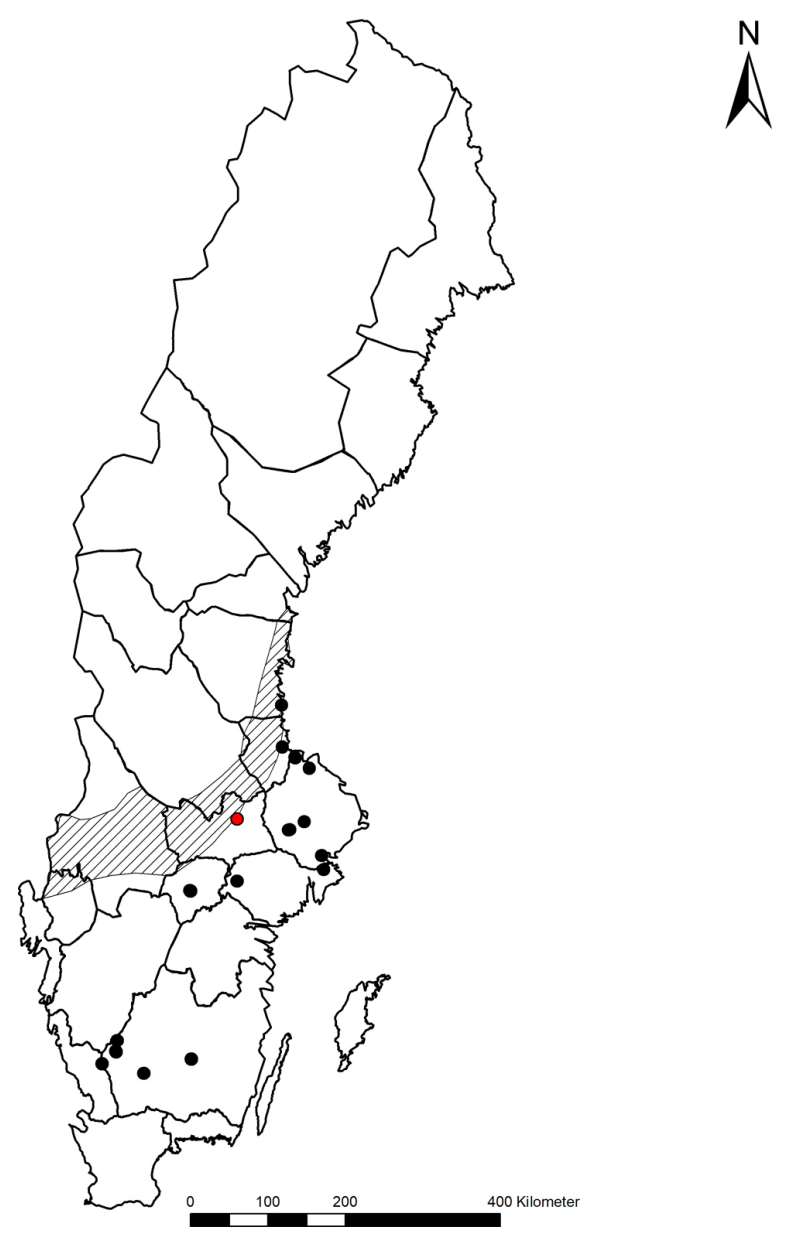

Fig. 1. Distribution of $K$. melanocephalus in Sweden as known in 2019. Note that one dot may represent more than one closely adjacent occurrence. The red spot represents the first known Swedish occurrence (Virsbo in the province of Västmanland 2015). The limes norrlandicus is marked as a dashed zone. The border-lines mark the Swedish provinces (Landskap)

terviewing the reporters/collectors it became clear that the species drew attention for the first time in the autumn 2019, after the alarm in the media, although in most cases it seemed possible that it had arrived earlier. A general observation was that the slugs disappeared after a few days of frost, late in October. There were, however, also scattered later observations of, in most cases single or a few, specimens. The latest observation dated from the 24th November (Huddinge, province Södermanland $\left.59^{\circ} 15.29^{\prime} \mathrm{N}, 18^{\circ} 00.71^{\prime} \mathrm{E}\right)$. No direct observation of damage to vegetables or ornamental parts was reported, but damage which could possibly be attributed to the species was found on hosta (Hosta spp.), horseradish (Amoracia rusticana), and rhubarb (Rheum spp.) in Virsbo. 


\section{EXTERNAL APPEARANCE AND GENITAL ANATOMY}

The Swedish specimens (all adult) reached a live length of 45-55 mm (one specimen $62 \mathrm{~mm}$ ) fully extended. The body colour is light grey-whitish. The rim of the pneumostome is somewhat paler than the body. The low tubercles are often light whitish. The narrow
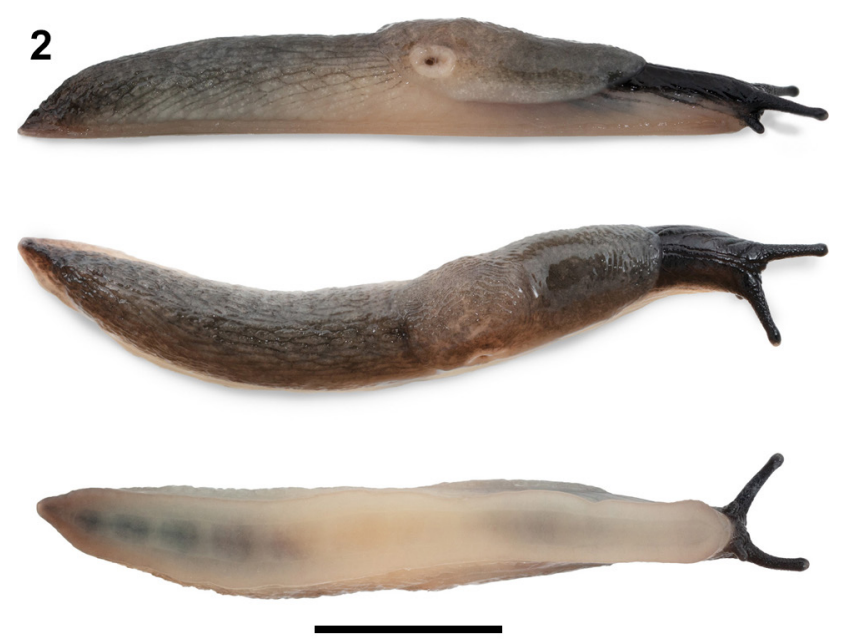

areas between the tubercles are darker, grey to greyblue and diffusely connected, sometimes forming a distinctive reticulate pattern as in Deroceras reticulatum (O. F. Müller, 1774). The posterior part of the mantle is in most specimens light grey-yellow to grey-white



Figs 2-3. Specimens of K. melanocephalus Sweden, province Västmanland, Virsbo October 15th, 2019. Photo: J. ROTH (Linköping). Scale bar $10 \mathrm{~mm}$

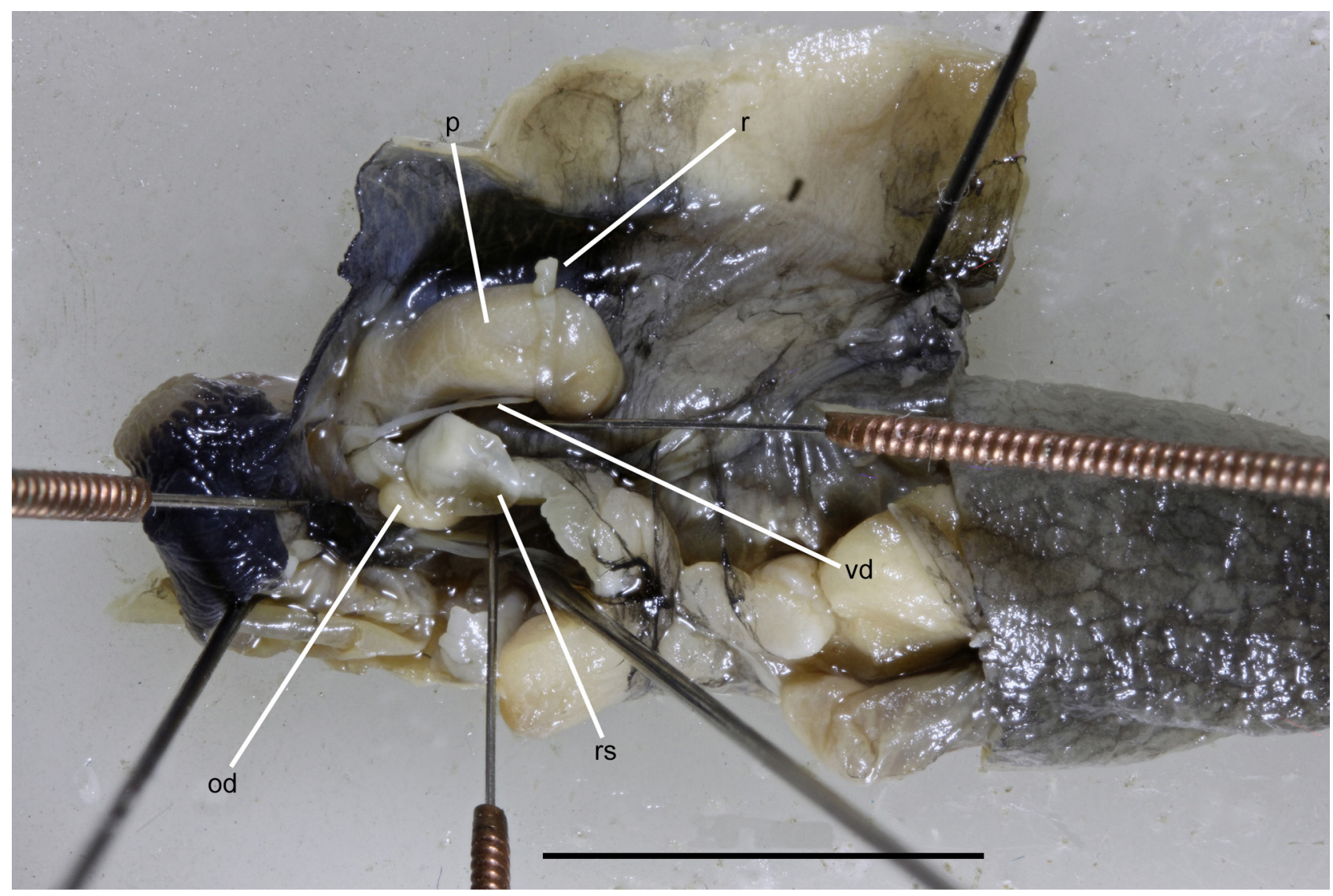

Fig. 4. Distal genitalia of K. melanocephalus. Specimen from Sweden: Västmanland, Virsbo October 15th, 2019. Abbreviations: od - oviduct; $\mathrm{p}$ - penis; $\mathrm{r}$ - retractor muscle; $\mathrm{rs}$ - receptaculum seminis; vd - vas deferens. Photo: C. JONSSON (GNM). Scale bar $10 \mathrm{~mm}$ 
and differs from the darker anterior part and the likewise darker tail-part of the body. The tubercles on the anterior part of the mantle form transverse lines; on the posterior (light) part they form concentric, irregular ellipses. Often the body sides, beneath the posterior part of the mantle, as well as the sides of the head are relatively light. The best external feature of $K$. melanocephalus is that the upper side of the head, as well as the tentacles are dark black to bluish black (Figs 2-3). In juveniles the colour may be less intense. The slime is colourless and watery. When the slug is disturbed it becomes whitish.

The distal genitalia are shown in a dissected specimen (Fig. 4). The penis is large and thick-walled, somewhat bean-shaped. Sometimes there is a fold, approximately at the bend in the middle, but in the Swedish specimens it is not as pronounced as in the Hungarian specimens (TURÓCI et al. 2020: fig. 4). It lacks appendages. The vas deferens is thin and delicate; it runs under the retractor muscle, is attached to the penis, and enters it almost apically. Contrary to the closely related genus Deroceras, there is no stimulator inside the penis, but several transverse folds, forming almost circular structures in the proximal (posterior) part (Fig. 5). The spermathecal duct

\section{DISCUSSION}

The knowledge of the biology of $K$. melanocephalus is only fragmentary. According to observations by MENG \& BÖSSNECK (1999) and BÖSSNECK \& FELDMANN (2003) in 1997, 1998 and 2002, juveniles could not be found until the end of June, reproductively mature specimens were found in the middle of September, and after that some further growth followed before the specimens reached their maximal length. This is in concordance with the observations in Sweden.

The sudden detection of the species in several localities in Sweden during 2019 also fits well with the situation in Latvia (https://www.mammadaba.lv/en/ news/3058-attention-slug-krynickillus-melanocephalus) and Hungary (TURÓCI et al. 2020). Concerning the speed of the spread, the information in the literature varies. In Germany there seems to be only a moderate spread in the period 1994-2002 (MENG \& BÖSSNECK 1999, BÖSSNECK \& FELDMANN 2003). The pattern of the Swedish occurrences of K. melanocephalus - scattered localities, without connection, over large areas - is typical of the initial phase of the haphazard passive anthropochorous dispersal of slugs (with plants, and presumably also soil) and it coincides very well with the observed initial spread of $A$. vulgaris in the country in the 1980s and 70s (VON PROSCHWITZ 1997).

So far, there seem to be few direct observations of damage by K. melanocephalus. No damage to plants

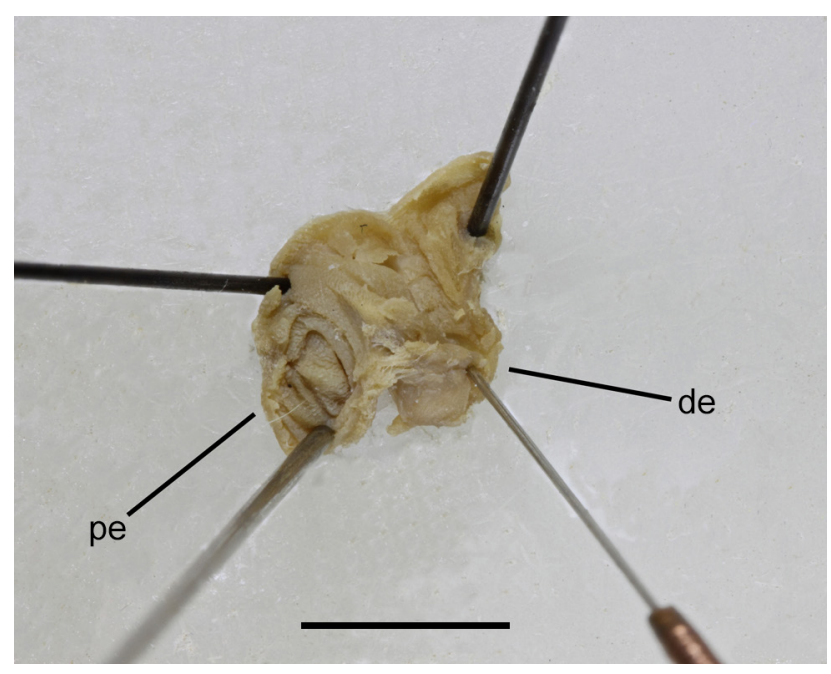

Fig. 5. Internal structures of the penis in another specimen from the same locality as Fig. 2. Abbreviations: de - distal end; pe - proximal end. Photo: C. JONSSON (GNM). Scale bar $5 \mathrm{~mm}$

is rather narrow and the length of the duct and the spermatheca approximately equals the length of the penis. For further details of the anatomy see WIKTOR (2000).

has so far been observed in Hungary (TURÓcI et al. 2020). DREIJERS et al. (2017) report damage in pumpkin cultivations in Latvia. There are different observations on the species' feeding habits. A. Stalažs (in mail to U. Bjelke, Swedish Species Information Centre) considers it more as a nuisance than a pest in gardens as it feeds on algae, rotten fruit and fungi in Latvia, whereas E. V. Schikov (also in mail to U. Bjelke) mentions damage by the slug to lettuce, cabbage, courgette (zucchini) and strawberries in Russia. Further research is needed to recognise the feeding preferences.

Within its natural range $K$. melanocephalus lives in woodland, from lowland to subalpine altitude, preferably close to water (LIKHAREV \& WIKTOR 1980, WIKTOR 2000). In Erfurt, Germany, apart from manmade habitats such as cemeteries, semi-natural woodland zones close to the river Gera, have been colonised by the species. In Lithuania, natural meadows in river valleys are mentioned by STALAŽs et al. (2018). Apart from purely man-made habitats E. V. Schikov (in mail to U. Bjelke) mentions secondary deciduous forests, raw floodplain, upland meadows and natural grey alder forests along rivers and streams as habitats colonised by the species in Tver, near Moscow, Russia. Tendencies of such spread into semi-natural and natural woodlands are already seen in Sweden. The observed mass-occurrence of K. mela- 
nocephalus in some localities in which it has been established also raises the question of its interaction/ competition with native slug species, and the risk for these to be disfavoured or out-competed - a problem which is not unknown concerning invasive slugs, e.g. the extremely invasive A. vulgaris (VON PROSCHWITZ 1997, RABITSCH 2006).

With high probability, the real number of localities of $K$. malanocephalus in Sweden is far greater than 30 , perhaps 10 times as many, and it might possibly also have spread geographically much further than is known. With this in mind, there seems to be little reason for taking extensive measures to eradicate it. The best strategy seems to be spreading information on the species and how to reduce its spread and how to control it at sites where it occurs. Considering the rapid spread and the observed mass occurrence, we are dealing with an invasive species, which will with high probability spread widely westwards and southwards over Europe in the coming years. Further studies are needed to evaluate whether it will also become an important pest species. Its ability to colonise semi-natural habitats and to appear in large populations is alarming. There is definitely a reason to watch out for K. melanocephalus!

\section{REFERENCES}

Bergey E. A., Figueroa L. L., Mather C. M., Martin R. J., RAY E. J., KURIEN J. T., WESTROP D. R., SURIYAWONG P. 2014. Trading in snails: plant nurseries as transport hubs for non-native species. Biological Invasions 16: 14411451. https://doi.org/10.1007/s10530-013-0581-1

BORLEIS F. 2018. Entdeckung von Krynickillus melanocephalus (Kaleniczenko 1851) in Sachsen. Mitteilungen der deutschen malakozoologischen Gesellschaft 98: 61-62.

BÖSSNECK U., FELDEMANN A. 2003. Zur Ausbreitung von Neozoa im Stadtgebiet von Erfurt am Beispiel der Landschnecken Cernuella neglecta (Draparnaud, 1805), Monacha cartusiana (O. F. Müller, 1774) and Krynickillus melanocephalus Kaleniczenko, 1851 (Mollusca: Gastropoda). Veröffentlichungen Naturkundemuseum Erfurt 22: 115-125.

BugA S., SINCHUK A. 2016. Alien species of terrestrial invertebrates in black book of invasive animal species in Belarus. In: Conferința "Sustainable use, protection of animal world and forest management in the context of climate change" Chișinău, Moldova, 12-13 octombrie 2016: 101.

Dreijers E., Stalažs A., PilĀTe, D., JakubĀNe I. 2017. The first notes on damage in horticulture made by Krynickillus melanocephalus Kaleniczenko, 1851 (Gastropoda: Agriolimacidae). Zinātnaski parktiskā konference "Lìdzvarota Lauksaimnecỉba" 23.02.2017. LLU, Jelgava, Latvija: 154-157.

\section{ACKNOWLEDGEMENTS}

I am very grateful to JONAS ROTH (Linköping) and Solveig WADELIUS (Virsbo, Västmanland), who draw my attention to the first occurrence of a new, unidentified slug in Sweden, and provided me with material and information. JOHAN LINNANDER (Swedish Environmental Protection Agency), and staff members of several of the Swedish County Administrative Boards (Länsstyrelsen) provided me with information on several further records. I also wish to express my thanks to ULF BJELKE (Swedish Species Information Centre), for interesting discussions and shearing valuable information with me. JONAS ROTH also took the photos of the living slugs. KATRIINA KÖNÖNEN gave me information on the occurrence of the species in Finland. BARNA PALL-GERGELY most generously gave me access to his (in press) paper on K. melanocephalus in Hungary. CHARLOTTE JONSSON helped me with the photos of the anatomy and GÖRAN ANDERSSON to adjust them for publication (both Gothenburg Natural History Museum), NIKLAS WENGSTRÖM (Gothenburg University) helped me with the distribution map. Finally I am grateful to HEIKE REISE and four further anonymous referees for constructive comments, which improved this paper.

FRIES M. 1948. Limes norrlandicus-studier, en växtgeografisk gränsfråga historiskt belyst och exemplifierad. Svensk Botanisk Tidskrift 43: 51-69.

Grossu A. V., LuPU D. 1957. Deroceras (Hydrolimax) melanocephalus, eine kaukasische Limacidae in Rumänien. Archiv für Molluskenkunde 86: 171-172.

Gural-Sverlova N. A., BAlashov I. A., GuRAl R. I. 2009. Sovremennoye rasprostranyenye nazyemnykh mollyuskov semeystva Agriolimacidae na territoryi Ukrainy. Ruthenica 19: 53-61.

Heller J. 2009. Land snails of the land of Israel. Pensoft, Sofia/Moscow.

Hutchinson J. M. C., Reise H., Robinson D. G. 2014. A biography of an invasive terrestrial slug: the spread, distribution and habitat of Deroceras invadens. NeoBiota 23: 17-24. https://doi.org/10.3897/neobiota.23.7745

KALENICZENKO J. 1851. Description d'un nouveau genre de Limaces de la Russie méridionale (Krynickillus). Bulletin de la Société Impériale des Naturalistes de Moscou 24: 215-228.

Korol E. N., KorniUsHiN A. V. 2002. Obnaruzhenye introducirovannogo vida slizney Krynickillus melanocephalus (Molluca, Gastropoda, Stylommatophora) v Kievye i predvaritelnye resultaty ego gelmintologicheskogo issledovanya. Vestnik Zoologii 36(6): 57-59.

KOZŁOWSKI J. 2012. The significance of alien and invasive slug species for plant communities in agrocenoses. 
Journal of Plant Protection Research 52: 67-76. https:// doi.org/10.2478/v10045-012-0012-9

LIKHAREV I. M., WIKTOR A. J. 1980. Slizni fauny SSSR i sopredelnykh stran (Gastropoda terrestrial nuda). Fauna SSSR. Mollyuski 3 (5). Nauka, Leningrad.

LIUKKO U.-M., KÖNÖNEN K. 2020. Viersalajit.fi Mustapääetana (Krynickillus melanocephalus). https://vieraslajit.fi/lajit/MX.5017394/show (accessed 15 March 2019).

MENG S., BÖSSNECK U. 1999. Krynickillus melanocephalus Kaleniczenko, 1851 in Deutschland eingeschleppt (Gastropoda: Stylommatophora: Agriolimacidae). Malakologische Abhandlungen, Staatliches Museum für Tierkunde Dresden 19: 303-309.

OsTROVSKY A. 2017. Novye nahodki sinantropnykh slizney Limacus flavus (Linnaeus 1758) i Krynickillus melanocephalus Kaleniczenko, 1851 (Mollusca, Gastropoda, Stylommatophora) v Belarusi. Ruthenica 27: 155-158.

Proschwitz T. VON 1997. Arion lusitanicus Mabille and A. rufus (L.) in Sweden: A comparison of occurrence, spread and naturalization of two alien slug species. Heldia 4: 137-138.

PROSCHWITZ T. VON 2009. Snigel - fridstörare i örtagården vetenskap och fakta. Bohusläns museums förlag, Göteborg.

Proschwitz T. VON 2014. Faunistical news from the Göteborg Natural History Museum 2013 - snails, slugs and mussels - with some notes on Sphaerium nucleus (S. Studer) - a freshwater mussel species new to Sweden. Göteborgs Naturhistoriska Museum Årstryck 2014: 39-52.

Proschwitz T. VON 2018. Faunistical news from the Göteborg Natural History Museum 2017 - Snails, slugs and mussels - with some notes on two imported slugs: Ariolimax columbianus (Gould) and Prophysaon foliolatum (Gould) and an introduced slug species Arion subfuscus (Draparnaud) s.s. new to Sweden. Göteborgs Naturhistoriska Museum Årstryck 2018: 29-45.

Proschwitz T. vON, REISE H., SCHLitT B., BREUGELMANS K. 2017. Records of the slugs Ariolimax columbianus (Ariolimacidae) and Prophysaon foliolatum (Arionidae) imported into Sweden. Folia Malacologica 25: 267-271. https://doi.org/10.12657/folmal.025.023

RABITSCH W. 2006. DAISIE - Arion vulgaris (MoquinTandon, 1855) Fact Sheet. Database of Delivering Alien Invasive Species Inventories for Europe. http:// www.europe-aliens.org (accessed 15 November 2019).

REISE H., HuTCHINSON J. M. C., FORSYTH R. G., FORSYTH T. J. 2000. The ecology and rapid spread of the terrestrial slug Boettgerilla pallens in Europe with reference to its discovery in North America. Veliger 43: 313-318.

REISE H., HuTCHINSON J. M. C., SCHUNACK S., SCHLITT B. 2011. Deroceras panormitanum and congeners from Malta and Sicily, with a redescription of the widespread pest slug as Deroceras invadens n. sp. Folia Malacologica 19: 201-223. https://doi.org/10.2478/v10125-011-0028-1

REISE H., SCHWARZER A.-K., HutChINSON J. M. C., SCHLITT B. 2020. Genital morphology differentiates three subspecies of the terrestrial slug Arion ater (Linnaeus,
1758) s.l. and reveals a continuum of intermediates with the invasive A. vulgaris Moquin-Tandon, 1855. Folia Malacologica 28: 1-34. https://doi.org/10.12657/ folmal.028.001

ROBINSON D. G. 1999. Alien invasions: the effect of the global economy on non-marine gastropod introductions into the United States. Malacologia 41: 413-438.

ROWSON B., TURner J., ANDERSON R., SYMONDSON B. 2014. Slugs of Britain and Ireland. Identification, understanding and control. Field Studies Council Publications, Telford.

SCHIKOV E. V. 2012. Krinickillus melanocephalus Kaliniczenko, 1851 (Mollusca, Gastropoda, Agriolimacidae) na Ruskoy ravninye. Zhivotnye: ekologya, biologya i okhrana. Materials of conference, Saransk: 375-378.

Simroth H. 1901. Die Nacktschneken des Russischen Reiches. Commissionäre der Kaiserlichen Akademie der Wissenschaften, St.-Petersburg. https://doi. org/10.5962/bhl.title.46383

STALAŽS A., DREIJERS E., IVINSKIS P., RIMŠAITE J., DŽIUGELIS M. 2018. Records of Krynickillus melanocephalus Kaleniczenko, 1851 (Gastropoda: Agriolimacidae) in Lithuania. Bulletin of the Lithuanian Entomological Society 1: 124-128.

SYSOEV A., SCHILEYKO A. 2009. Land snails and slugs of Russia and adjacent countries. Pensoft, Sofia/Moscow. [Krynickillus melanocephalus on pp. 145-146].

ŠTEFFEK J., STALAŽS A., DREIJERS E. 2008. Snail fauna of the oldest cemeteries from Riga (Latvia). Malacologica Bohemoslovaca 7: 79-80.

Turóci A., FeHÉr Z., KRÍZsIK V., PÁll-Gergely B. 2020. Two new alien slugs, Krynickillus melanocephalus Kaleniczenko, 1851 and Tandonia kusceri (H. Wagner, 1931), are already widespread in Hungary. Acta Zoologica Academiae Scientarum Hungaricae 66: 265282. https://doi.org/10.17109/AZH.66.3.265.2020

URBAŃSKI J., WIKTOR A. 1968. Beiträge zur Kenntnis bulgarischer Nacktschnecken (Moll., Pulm.) (Systematische, zoogeographische und ökologische Studien über die Mollusken der Balkanhalbinsel VIII). Bulletin de la Société des Amis des Sciences et des Lettres de Poznań, series D, Sciences Biologiques 8 [1967]: 47-95.

WELTER-SCHULTES F. 2012. European non-marine molluscs, a guide for species identification. Planet Poster Edition, Göttingen.

WIKTOR A. 1971. Die von der niederländischen biologischen Expedition in die Türkei in 1959 gesammelten Nacktschnecken (Milacidae und Limacidae, Pulmonata mit Beschreibung einer neuen Deroceras-Art aus dem Balkan-Gebiet und der Türkei. Zoologische Meddelingen Rijksmuseum van natuurlijke historie te Leiden 45: 261-280.

WikTOR A. 1983. The slugs of Bulgaria (Arionidae, Milacidae, Limacidae, Agriolimacidae - Gastropoda Stylommatophora). Annales Zoologici 37: 71-206.

WIKTOR A. 2000. Agriolimacidae (Gastropoda: Pulmonata) a systematic monograph. Annales Zoologici 49: 347590. 
WIKTOR A. 2004. Ślimaki lądowe Polski. Wydawnictwo Mantis, Olsztyn.

WIKTOR A. 2007. A check-list of terrestrial slugs of Turkey with some new data and a description of a new species (Gastropoda Terrestria Nuda). Folia Malacologica 15: 95-107. https://doi.org/10.12657/folmal.015.011

WIKTOR A., JURKOWSKA J. 2007. The collection of terrestrial slugs (Gastropoda: Pulmonata) at the Museum of Natural History, Wrocław University (Poland). Folia
Malacologica 15: 83-93. https://doi.org/10.12657/folmal.015.010

ZająC K. S., GaWe€ M., FilipiaK A., Kramarz P. 2017. Arion vulgaris Moquin-Tandon, 1855 - the aetiology of an invasive species. Folia Malacologica 25: 81-93. https://doi.org/10.12657/folmal.025.008

Received: May 22nd, 2020

Revised: July 27th, 2020

Accepted: July 31st, 2020

Published on-line: August 11th, 2020 